\title{
Postoperative wound infection after obstetrics and gynaecology surgeries: A study from the tribal tertiary healthcare centre
}

\begin{abstract}
Parmar M. ${ }^{1}$, Damor M. ${ }^{2 *}$
DOI: https://doi.org/10.17511/joog.2020.i04.04

1 Monika Parmar, Associate Professor, Department of Obstetrics and Gynaecology, Dungarpur Medical College, Dungarpur, Rajasthan, India.

2* Mahendra Damor, Associate Professor, Department of General Surgery, Dungarpur Medical College, Dungarpur, Rajasthan, India.

Aims and Objectives: the study was conducted to find out the incidence of postoperative wound infection among obstetric and gynaecological surgeries in the tribal area of Rajasthan region with the objective to identify various preventable risk factors and common responsible pathogen. Material and methods: It was a prospective study conducted in the department of Gynaecology in Government Medical College and Hospital, Dungarpur during the period of six months from August 2019 to January 2020. Results: Out of 300 surgeries performed, 210 surgeries were obstetrics and 90 surgeries were gynaecological. The mean age of obstetrics cases was $26.89 \pm 2.5$ years and of gynaecological cases was $48.22 \pm 4.8$ years. Frequency of wound infection in obstetrics cases was $5.23 \%$ (11 cases) and was $11.11 \%$ (10 cases) in gynaecological surgeries with a total frequency of $7 \%$ (21 cases). Mean postoperative day of wound infection was $9.81 \pm 5.6$, mean postoperative hospital stay was $8.10 \pm 5.6$ days and the mean duration of surgery was $1.29 \pm 0.45$ hours. Body mass index (BMI) was $>25$ (obese) in $61.90 \%$ of infected cases. 15 patients (10.41\%) out of 144 patients who did not receive antibiotic prophylaxis, developed wound infection. On culture, Escherichia Coli (E.coli) was found to be the most common responsible pathogen (38.09\%) followed by Klebsiella species and Staphylococcus aureus (19.04\%). Conclusion: Early identification of various risk factors for postoperative wound infection in obstetric and gynaecological surgeries is essential to prevent further morbidities.
\end{abstract}

Keywords: Wound infection, Obstetric, Abdominal surgery, Risk factors, Gynaecology

Corresponding Author

Mahendra Damor, Associate Professor, Department of General Surgery, Dungarpur Medical College, Dungarpur, Rajasthan, India.

Email: docpages11@gmail.com
How to Cite this Article

Parmar M, Damor M. Postoperative wound infection after obstetrics and gynaecology surgeries: A study from the tribal tertiary healthcare centre. Obs Gyne Review J Obstet Gynecol. 2020;6(4):91-95. Available From

https://obstetrics.medresearch.in/index.php/joog/art icle/view/118
To Browse

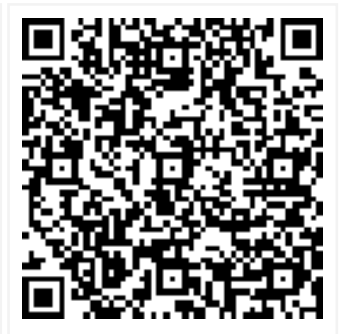

Manuscript Received 2020-07-29

Conflict of Interest No
Review Round 1 2020-08-09

Funding $\mathrm{Nil}$
Review Round 2 2020-08-19

Ethical Approval Yes
Review Round 3

Accepted 2020-08-26 (c) 2020 by Monika Parmar, Mahendra Damor and Published by Siddharth Health Research and Social Welfare Society. This is an
Open Access article licensed under a Creative Commons Attribution 4.0 International License https://creativecommons.org/licenses/by/4.0/ unported [CC BY 4.0]. 


\section{Introduction}

Postoperative surgical site infection is the second most common infection of all the nosocomial infections among hospital patients and accounts for significant morbidity of around $8-10 \%$ in obstetric and gynaecological surgeries $[1,2]$.

Various co-morbidities like diabetes mellitus, thyroid disorders, bronchial asthma, renal disorders and other immunosuppressive disorders are known risk factors for postoperative infection. Other risk factors which also contributes to postoperative infectious morbidity are obesity, emergency surgery, prophylactic antibiotic, prolonged hospital stay etc [3-5].

In a tribal area like ours, postoperative complications after the discharge of the patient can cause serious morbidities and mortality because of the lack of primary level healthcare in many areas. By keeping the above points in mind, the present study was conducted to know about various risk factors responsible for post-operative surgical wound infection so that early intervention can be done to prevent further morbidities.

\section{Material and Methods}

It was a prospective study conducted in the department of Gynaecology in Government Medical College and Hospital, Dungarpur during the period of six months from August 2019 to January 2020.

Type of study: Longitudinal prospective study

Inclusion criteria: All surgeries performed in the department of obstetrics and gynaecology during the study period.

\section{Exclusion criteria}

01. Patients operated in some other institute.

02. Patients with associated co-morbidities like diabetes/ hypertension/ bronchial asthma/ thyroid disorders/ renal disease or any immunosuppressive disorders.

Sample size and sampling: Total 300 cases underwent caesarian sections or abdominal gynaecological surgeries were included in the study. Presence of purulent discharge from the wound with or without a positive bacteriological culture was considered as wound infection. All the data regarding preoperative, intraoperative and postoperative information were filled in proforma and data was analyzed statistically.
Ethical clearance and patient consent: Clearance was taken from the institutional ethical committee and a well informed written consent was also taken from all the study participants.

Statistical analysis: Statistical analysis was done using SPSS 19.0 software.

\section{Results}

Based on our inclusion criteria, 300 patients were included in the present study. Out of 300 surgeries performed, 210 surgeries were obstetrics and 90 surgeries were gynaecological. The mean age of obstetrics cases was $26.89 \pm 2.5$ years and of gynaecological cases was $48.22 \pm 4.8$ years. Frequency of wound infection in obstetrics cases was $5.23 \%$ ( 11 cases) and was $11.11 \%$ (10 cases) in gynaecological surgeries with a total frequency of $7 \%$ (21 cases). Distribution of elective and emergency surgeries along with the frequency of wound infection is depicted in Table 1.

Table-1: Distribution of elective and emergency surgeries in the present study.

\begin{tabular}{|l|l|l|}
\hline Type of surgery & \multicolumn{1}{|c|}{ Number } & \multicolumn{1}{c|}{ Frequency of wound infection } \\
\hline Elective & $238(79.33 \%)$ & $8(3.36 \%)$ \\
\hline Emergency & $62(20.66 \%)$ & $13(20.96 \%)$ \\
\hline Total & 300 & 21 \\
\hline
\end{tabular}

Among all the study participants, the mean

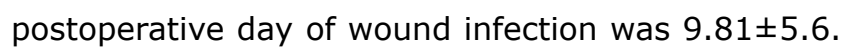
The mean postoperative hospital stay was $8.10 \pm 5.6$ days. Mean duration of surgery was $1.29 \pm 0.45$ hours (Table 2 ).

Table-2: Various intraoperative and postoperative data of study participants.

\begin{tabular}{|l|l|}
\hline \multicolumn{1}{|c|}{ Data } & \multicolumn{1}{|c|}{ Mean \pm SD } \\
\hline Postoperative day of infection & $9.81 \pm 5.6$ \\
\hline Postoperative hospital stay & $8.10 \pm 5.6$ \\
\hline Duration of surgery & $1.29 \pm 0.45$ \\
\hline
\end{tabular}

Body mass index (BMI) was >25 (obese) in $61.90 \%$ of infected cases suggestive of statistically significant ( $p$-value $<0.0001$ ) association between

Table-3: Distribution of post-operative wound infection as per body mass index (BMI).

\begin{tabular}{|l|l|l|}
\hline \multicolumn{1}{|c|}{ BMI } & \multicolumn{1}{c|}{ Number of infected cases } & \multicolumn{1}{c|}{$\%$} \\
\hline$<20$ (normal) & 2 & 9.52 \\
\hline $21-25$ (overweight) & 6 & 28.57 \\
\hline$>25$ (obese) & 13 & 61.90 \\
\hline Total & 21 & 100 \\
\hline
\end{tabular}

High BMR and post-operative wound infection 
(Table 3)

Among 300 study participants, 156 patients had a history of receiving preoperative antibiotic prophylaxis. 15 patients $(10.41 \%)$ out of 144 patients who did not receive antibiotic prophylaxis, developed wound infection while only 6 (3.84\%) out of 156 patients who received antibiotic prophylaxis, developed wound infection. (Table 4)

Table-4: Distribution of antibiotic prophylaxis among study participants.

\begin{tabular}{|l|l|l|}
\hline & \multicolumn{1}{|c|}{$\begin{array}{c}\text { Antibiotic prophylaxis } \\
\text { was given }\end{array}$} & \multicolumn{1}{|c|}{$\begin{array}{c}\text { No Antibiotic } \\
\text { prophylaxis }\end{array}$} \\
\hline $\begin{array}{l}\text { Cases with Wound } \\
\text { infection }\end{array}$ & 6 & 15 \\
\hline $\begin{array}{l}\text { Cases with no Wound } \\
\text { infection }\end{array}$ & 150 & 129 \\
\hline Total & 156 & 144 \\
\hline
\end{tabular}

Pus for culture was sent in all the infected cases. Escherichia Coli (E.coli) was found to be the most common responsible pathogen (38.09\%) followed by Klebsiella species and Staphylococcus aureus (19.04\%). Methicillin-resistant Staphylococcus aureus (MRSA) (9.52\%) and Pseudomonas species $(4.76 \%)$ were also found in a few cases. No organism was grown in $9.52 \%$ cases (Table 5 ).

\section{Table-5: Distribution of causative microorganisms in post-operative wound infection.}

\begin{tabular}{|l|l|l|l|}
\hline S.No. & Causative Micro-organism & Number of cases & $\%$ \\
\hline 1 & E.Coli & 8 & 38.09 \\
\hline 2 & Klebsiella Species & 4 & 19.04 \\
\hline 3 & Staphylococcus Aureus & 4 & 19.04 \\
\hline 4 & MRSA & 2 & 9.52 \\
\hline 5 & Pseudomonas & 1 & 4.76 \\
\hline 6. & No organism grew & 2 & 9.52 \\
\hline Total & & 21 & 100 \\
\hline
\end{tabular}

\section{Discussion}

Among 300 patients underwent caesarian section or major abdominal surgeries, 21 patients developed postoperative wound infection (7\%) in the present study. The incidence of postoperative wound infection was found to be similar to earlier studies. Mishriki SF et al performed a similar study in 1990 and found the incidence of $7.3 \%$. Similarly, Rahman Jahanara found the incidence of $7.54 \%$ and Bhadauria AR et al found the incidence of $6.12 \%$ [68].

In the present study, the mean age of obstetrics
Cases was $26.89 \pm 2.5$ years and of gynaecological cases was $48.22 \pm 4.8$ years. In another study by $A$ Nuwal, the mean age of obstetric cases was $27 \pm 5.5$ and of gynaecological cases was $47.67 \pm 7.8$ [9].

Incidence of postoperative wound infection was much more in emergency surgeries (20.96\%) than in elective cases (3.36\%). This finding was similar to the study performed by Bhadauria AR et al in which the incidence of postoperative wound infection was $51.17 \%$ in emergency cases and $15.87 \%$ in elective, clean cases. These findings were also comparable to the study done by Rahman Jahanara et al $[7,8]$.

In the present study, the mean postoperative day of wound infection was $9.81 \pm 5.6$, mean postoperative hospital stay was $8.10 \pm 5.6$ days and the mean duration of surgery was $1.29 \pm 0.45$ hours.

Some studies in the past could not confirm the duration of surgery as a risk factor for postoperative wound infection. (10, 11) In contrast, a recent study done by Arabshahi et al showed a significant difference in the duration of surgery between patients with and without postoperative wound infection [12].

BMI was $>25$ in $61.90 \%$ of infected cases of the present study which indicates higher BMI as an important risk factor for postoperative wound infection. Similar results were found in some previous studies [12-14]. In contrast, in a study by Kamat AA et al, BMI was not found as a predictor of postoperative infection [15].

15 patients (10.41\%) out of 144 patients who did not receive antibiotic prophylaxis, developed wound infection while only $6(3.84 \%)$ out of 156 patients who received antibiotic prophylaxis, developed wound infection. The difference in infection rate between patients with and without antibiotic prophylaxis was statistically significant ( $p$-value < $0.0001)$. The findings were similar to previous studies. Kamat et al found that $26.9 \%$ of patients who did not receive antibiotic prophylaxis, developed wound infection compared to $7.9 \%$ of those who received antibiotic prophylaxis [15]. Beattie PG et al and Witt $A$ et al also found antibiotic prophylaxis as the most important protective factor to reduce postoperative wound infection $[16,17]$.

Escherichia Coli (E.coli) was found to be the most common responsible pathogen (38.09\%) followed by Klebsiella species and Staphylococcus aureus (19.04\%). Methicillin-resistant Staphylococcus 
Aureus (MRSA) (9.52\%) and Pseudomonas species $(4.76 \%)$ were also found in a few cases. No organism was grown in $9.52 \%$ cases. Similar results were found in the previous study by Bhadauriya et al with E.coli as the most common responsible pathogen $(36.62 \%)$ followed by Klebsiella species $(6.10 \%)$. In contrast, Staphylococcus aureus was found to be the most common pathogen responsible [18-22].

\section{Limitations}

01 . The study was conducted over a short period

02. Small sample size

03. Short follow-up

04. Results cannot surely be generalized to another rural or urban region.

\section{Conclusion}

The incidence of postoperative wound infection in obstetric and gynaecological surgeries was $7 \%$ in the present study which was comparable to previous literature. Many patients with associated comorbidities like diabetes, asthma, renal disorders and other immunosuppressive disorders were excluded from the study to find out new risk factors for postoperative infection other than established risk factors. Incidence of infection was more in emergency cases than elective cases because elective cases are clean and proper preoperative workup with antibiotic prophylaxis is usually done in elective cases. High BMI and lack of antibiotic prophylaxis were the important risk factor responsible for post-operative wound infection. $E$. Coli was found to be the most common responsible pathogen for wound infection. Early identification of risk factors and prompt intervention can prevent further morbidities due to post-operative surgical site infection.

\section{What does this study add to the existing knowledge}

Apart from various known risk factors like diabetes and other immunosuppressive disorders, this study adds many other preventable risk factors which can be minimized preoperatively to prevent morbidity due to post-operative surgical site infection. Further, this type of study has not been conducted in the tribal area of southern Rajasthan yet so this information can be useful for further studies in the future.

\section{Author's contribution}

Dr. Monika Parmar: Study concept and design, revision and proof.

Dr. Mahendra Damor: Data analysis, statistics and final drafting.

\section{Reference}

01. Amenu D, Belachew T, Araya F. Surgical site infection rate and risk factors among obstetric cases of Jimma University specialized hospital, southwest ethiopia. Ethiop J Health Sci. 2011;21(2)91-100.

doi: 10.4314/ejhs.v21i2.69049 [Crossref]

02. Cruse PJ, Foord R. The epidemiology of wound infection, A 10-year prospective study of 62,939 wounds. Surg Clin North Am. 1980;60(1)27-40. doi: 10.1016/s0039-6109(16)42031-1 [Crossref]

03. Rock JA, Jones HW. Te Linde's Operative Gynecology. 10th ed, 2008.

[Crossref]

04. De la Fuente Fonnest I, Stigsby B, Heisterberg L. Risk factors in wound infections after laparotomy in obstetrics and gynaecology. Dan Med Bull. 1999;46(3)254-257.

[Crossref]

05. Olsen MA, Butler AM, Willers DM, Devkota P, Gross GA, Fraser VJ. Risk factors for surgical site infection after low transverse cesarean section. Infect Control Hosp Epidemiol. 2008;29(6)477-484.

doi: $10.1086 / 587810$ [Crossref]

06. Rahman Jahanara, Sultana Nasreen, Hasan Munir, Begum Hosne Ara. Factors of postoperative wound infections in abdominal surgeries of Obstetrics and Gynaecology, Dept. J Dhaka Med Coll Hos. 2011;18(1)39-42.

doi: $\quad 10.3329 /$ jdnmch.v18i1.12239 [Crossref]

07. Bhadauria AR, Hariharan C. Clinical study of post operative wound infections in obstetrics and gynaecological surgeries in a tertiary care set up. Int J Reprod Contracept Obstet Gynecol. 2013;4(2)631-638.

doi: $10.5455 / 2320-1770$. ijrcog20131228 [Crossref] 
08. Mishriki SF, Law DJ, Jeffery PJ. Factors affecting the incidence of postoperative wound infection. J Hosp Infect. 1990;16(3)223-230. doi: 10.1016/0195-6701(90)90110-a [Crossref]

09. A Nuwal, VR Shrivastava, A Giri. A prospective study of wound infections after laparotomy in obstetrics and gynaecology department. Nep Med Coll J. 2012;14(4)267-270.

[Crossref]

10. Tran TS, Jamulitrat S, Chongsuvivatwong V, Geater A. Risk factors for postcesarean surgical site infection. Obstet Gynecol. 2000;95(3)367371.

doi: 10.1016/s0029-7844(99)00540-2 [Crossref]

11. Suonio S, Saarikoski S, Vohlonen I, Kauhanen O. Risk factors for fever, endometritis and wound infection after abdominal delivery. Int J Gynaecol Obstet. 1989;29(2)135-142.

doi: 10.1016/0020-7292(89)90843-6 [Crossref]

12. Arabshahi KS, Koohpayezade J. Investigation of risk factors for surgical wound infection among teaching hospitals in Tehran. Int Wound $\mathrm{J}$. 2006;3(1)59-62.

doi: $10.1111 /$ j.1742-4801.2006.00176.x [Crossref]

13. De la Fuente Fonnest I, Stigsby B, Heisterberg L. Risk factors in wound infections after laparotomy in obstetrics and gynaecology. Dan Med Bull. 1999;46(3)254-257.

[Crossref]

14. Ezechi OC, Edet A, Akinlade H, Gab-Okafor CV, Herbertson E. Incidence and risk factors for caesarean wound infection in Lagos Nigeria. BMC Res Notes. $2009 ; 2 ; 186$.

doi: $10.1186 / 1756-0500-2-186$ [Crossref]

15. Kamat AA, Brancazio L, Gibson M. Wound infection in gynecologic surgery. Infect Dis Obstet Gynecol. 2000;8(5-6)230-234.

doi: $10.1155 / \mathrm{S} 1064744900000338$ [Crossref]
16. Beattie PG, Rings TR, Hunter MF, Lake Y. Risk factors for wound infection following caesarean section. Aust NZJ Obstet Gynaecol. $1994 ; 34(4) 398-402$.

doi: $10.1111 /$ j.1479-828x.1994.tb01256.x [Crossref]

17. Witt A, Doner $M$, Petricevic $L$, Berger $A$, Germann $P$, Heinze $G$, et al. Antibiotic prophylaxis before surgery vs after cord clamping in elective cesarean delivery- a double-blind, prospective, randomized, placebocontrolled trial. Arch Surg. 2011;146(12)14041409.

doi: 10.1001/archsurg.2011.725 [Crossref]

18. De Araujo Madeira MZ, Trabasso P. Surgical site infections in women and their association with clinical conditions. Rev Soc Bras Med Trop. 2014;47(4)457-461.

doi: 10.1590/0037-8682-0125-2014 [Crossref]

19. Bangal VB, Borawake SK, Shinde KK, Gavhane SP, Bangal Professor VB. Study of surgical site infections following gy $\neg$ naecological surgery at tertiary care teaching hospital in ru $\neg$ ral India. Int J Biomed Res. 2014.

[Crossref]

20. De Nardo P, Gentilotti E, Nguhuni B, Vairo F, Chaula Z, Nicastri $E$, et al. Post-caesarean section surgical site infec $\neg$ tions at a Tanzanian tertiary hospital- A prospective ob $\neg$ servational study. J Hosp Infect. 2015;93(4)1-5. doi: $10.1016 /$ j.jhin.2016.02.021 [Crossref]

21. Johnson ET. Nosocomial infection- Update. J Natl Med As $\neg$ soc. 1983;75(2)147-154.

[Crossref]

22. Ming DY, Chen LF, Miller BA, Sexton DJ, Anderson DJ. The impact of depth of infection and postdischarge sur $\neg$ veillance on rate of surgical-site infections in a network of community hospitals. Infect Control Hosp Epidemiol. 2015;33(03)276-282. doi: $10.1086 / 664053$ [Crossref] 